\title{
Chapter 8 Setting the Scene: Viewing the World as Interconnected Systems
}

\author{
Kristin Vala Ragnarsdottir
}

\begin{abstract}
This chapter gives a conceptual overview for viewing the world as interconnected systems. Systems have interconnected stock and flows, and change in one part of the system has nonlinear effects on the whole system due to causes and effects that can be mapped. The systems that are outlined are the Earth system, the economic system, the financial system, the education system, and the innovation system. Other systems that are briefly mentioned include the food system, the biological system, the climate system, and community systems. All of these systems (and more) are interconnected in a complex manner, and to achieve a regenerative global system, it is not enough to focus in our education system on environmental and sustainability literacy but on an overarching transformation literacy as outlined in this book. Thus, due to of the interconnectedness of the various systems, holistic education and environmental policy making alone will not achieve the transformations called for.
\end{abstract}

Keywords Interconnected systems $\cdot$ Earth system $\cdot$ Economic system $\cdot$ Financial system $\cdot$ Education system $\cdot$ Innovation system $\cdot$ Transformation literacy

\subsection{Introduction}

Let us consider how a sustainable world might look like. Many ideas and images have been put forward and will not be summarized here. Only the definition of the system's thinker Alan AtKisson (2008, 2010) is given because it is holistic and serves the systems approach of this book section. He defines sustainability as a set of conditions and trends in a given system that can continue indefinitely, and sustainable development as a directed process and systemic change in the direction of sustainability. AtKisson's seven steps toward sustainability are also based on systems thinking: think long term; understand systems; know limits; protect nature; change commence; show equity; and support entrepreneurship and innovation. These

\footnotetext{
K. V. Ragnarsdottir $(\bowtie)$

Institute of Earth Science, University of Iceland, Reykjavik, Iceland

e-mail: vala@hi.is
} 
definitions and steps show the importance of understanding systems and interconnectedness. He further outlines six traits that characterize a system's thinker: S/he looks for a big picture; looks for cycles; looks for causes and effects; sees how things within the system change with time; looks for new angles; investigates causes of short-term and long-term actions; and finds unexpected connections. Our thesis is that the systems perspective gives the conceptual framing to explore essentials and underlying principles of regenerative systems and how they can guide the move toward regenerative civilizations. In this context, regenerative is more than sustainable; it does not only aim for giving future generations a chance based on current resources, but also focuses on regeneration of nature and communities-in order to give future generations a better chance than the current generation has today. I propose here that we can add four steps to AtKissons's systems thinking as a basis for a regenerative world: think long term; understand systems; know limits; protect nature; apply ecosystem principles to agriculture and forestry; redefine the purpose of the economy; change commence; show equity; build communities; change international law; and support entrepreneurship and innovation.

Part two of this book explores what kind of systems would reflect a new worldview and how they can be co-constructed toward regenerative systems based on a partnership with life's evolution and enhanced transformation literacy (Kuenkel, 2019). The series of chapters (9-14) highlight emerging bottom-up systems that allow communities for change to take charge of their future and connect local to global system designs that are likely to support pathways toward a regenerative world. The contributions show concepts and implementation attempts of regenerative approaches to humanto-human and human-to-nature interactions that showcase a new operating model for humankind. The contributors come from a wide-ranging spectrum of expertise from all over the world to illustrate that the entry points for transformative change toward regenerative civilizations may come from very different angles and perspectives. The contributors showcase exemplary systems that model collective stewardship of planetary well-being.

It is from this system perspective that we investigate current influential global systems in this section. Current civilizations operate within the Earth system, the global economic and financial system, global to national educational systems, and innovation systems. There are other systems involved, and they cannot all be outlined here. The important angle presented here is that all of these systems are interconnected and operate in unison. Therefore, they need to be studied together and connection points found between the systems in order to be able to act collectively. 


\subsection{Systems}

\subsubsection{The Earth System}

The Earth system comprises the geosphere, biosphere, hydrosphere, and atmosphere, and these four spheres are a part of the Earth's critical zone that comprises the whole Earth system. If left alone, the Earth system seeks a balance through natural processes, and change is slow, driven by natural cycles. These natural cycles include plate tectonics and movement of the Earth's crust on the plastic mantle-in cycles of millions of years; evolution of life on Earth over three billion years that influence the amount of oxygen and carbon dioxide in the atmosphere and hence affect climate; Earth's rotation on its elliptical axis and rotation around the Sun (100,000 year Milankovitch cycles) that affects climate and tips the Earth in and out of ice ages; and most recently the exponential growth of population on Earth over the past century, and was allowed by the "advancement" of technology and agricultural practices. Man's influence on Earth, in particular in burning fossil fuels that took biogeochemical processes and geological forces millions of years to produce, is much faster (decades) than the previously outlined natural cycles (hundreds of thousands to millions of years). Therefore, man now has a much more profound effect on Earth than natural cycles and hence the Earth system. We therefore live in a new geological epoch, the Anthropocene, a time period that started with the Great Acceleration in industrialization and globalization 70 years ago (Steffen et al., 2015), the post-WWII period, during which socioeconomic and Earth system trends increase at an exponential rate and also mark the beginning of the atomic age, evidence of which is found in sedimentary layers in oceans and lakes across the Earth (Zalasiewicz et al., 2021).

Man's influence on the Earth system is primarily through the extraction of natural resources that are converted to consumption goods (including fertilizer for food production) through work and the use of energy. With global markets and free trade agreements, goods and financial flows have limited restrictions, under the current dominating economic paradigm: neoliberal market economy. Over the past 50 years, compounding driving demands for energy and materials has been caused by the doubling of the human population, fourfold growth of the global economy, and tenfold growth of global trade (IBPES, 2019). Ecological signs of the declining state of the Earth include that wild animals have been reduced by $60 \%$ since 1970 ; there has been an $85 \%$ degradation of land ecosystems, and $65 \%$ degradation in ocean ecosystems; and one million species are endangered (IBPES, 2019). Furthermore there has been a $75 \%$ reduction in insect abundance in Germany and elsewhere since 1990 s, and $30 \%$ of the world's soils are severely degraded. There now is talk of 60 harvests being left (FAO, 2015) unless agrological practices change drastically. Humanity and all life on Earth are in dire straits. 
I hence come to the conclusion, that the destruction of the natural world and the accompanying warming of the planet due to burning of fossil fuels, still the dominating world energy production method $(80 \%)$, is driven by the global socioeconomic system. Hence, in order to get away from the destructive path that humankind is on today, it is necessary to change the economic system. The economic system is manmade, and we therefore can redefine its purpose. With no nature, there is no economy and no future.

\subsubsection{The Economic System}

Neoclassical economics emerged in around 1900 to compete with the earlier theories of classical economics. It is a broad theory that focuses on supply and demand as the driving forces behind the production, pricing, and consumption of goods and services (Kenton \& Kelly, 2021). Neoclassical economists argue that the consumer's perception of a product's value is the driving factor in its price and they call the difference between actual production costs and retail price the economic surplus. In 1947, a meeting was held with economists, historians, and philosophers attending in Mont Pelerin in Switzerland from which the Mont Pelerin Society emerged (Hartwell, 1995). With the action plan laid out in the so-called Powell Memorandum (Powell, 1971), many societies, starting from the USA, embarked on a plan for an economy built on neoliberalism. Neoliberalism is a policy model that encompasses both politics and economics and seeks to transfer the control of economic factors from the public sector to the private sector. Many neoliberalism policies enhance the workings of free market capitalism and attempt to place limits on government spending, government regulation, and public ownership (Kenton \& Westfall, 2020). The policies of neoliberalism typically supports fiscal austerity, deregulation, free trade, privatization, and a reduction in government spending. Neoliberalism was adopted as economic policies of Ronald Reagan in the USA and Margaret Thatcher in the UK in the 1980s and from there spread around the world. There are many criticisms of neoliberalism, including its tendency to endanger democracy, workers' rights, judicial law, communications, education, and sovereign nations' right to self-determination.

The current neoliberal economic policy system thrives on perpetual growth. As outlined above, the economic system with focus on natural resource extraction, production, and consumption is driving the destruction of the natural world. The national growth mantra is fueled by international institutions such as the World Bank, the International Monetary Fund, and the OECD as well as by governments across the world, even though economists such as Kenneth Boulding stated in the 1960s that "anyone who believes that exponential growth can go on forever in a finite world is either a madman or an economist." ${ }^{1}$ His physicist colleague at the University of Colorado, Boulder-Albert Allen Bartlett—devoted a large part of his life to

\footnotetext{
${ }^{1}$ U.S. Congress, Energy Reorganization Act of 1973: Hearings, Ninety-third Congress, First Session, on H.R. 11,510 (U.S. Government Printing Office, 1973), p. 248.
} 
attempting to explain the consequences of exponential growth, and he stated repeatedly that "the greatest shortcoming of the human race is our inability to understand the exponential function." 2 As an example, 3.5\% economic growth which governments like to see annually is based on the throughput of goods and services to double in 20 years; $7 \%$ economic growth as observed in China in recent years doubles the flow in 10 years. Since the basis of the economy are natural resources (e.g., Meadows et al., 1972; Sverdrup \& Ragnarsdottir, 2014; Ragnarsdottir \& Sverdrup 2015) on a limited Earth, the economy cannot sustain such growth into this century due to us entering the era of peak production of resources that are used in our techno-centric world.

The Limits to Growth report to the Club of Rome in 1972 (Meadows et al., 1972, 1992, 2004) demonstrated through system dynamics modeling the consequences of exponential population growth. They generated eight scenarios, one of which was "business as usual (BAU)," i.e., continuation of exponential population growth and accompanying exponential extraction of and production from natural resources (including energy) and the coincident decline of the environment. Strong political forces ridiculed the Limits to Growth study (see overviews in Kanninen, 2013; Nörgård et al., 2010), and hence, we have sadly followed the BAU path (Turner, 2012, 2014). Almost 50 years on, we are entering the century where the consequences of exponential growth are widely visible, through population increase, entering the era of resource scarcity, and severe environmental degradation (Bardi, 2011; Bradshaw et al., 2021; Heinberg, 2001, 2005, 2011; IBPES, 2019; Sverdrup \& Ragnarsdottir, 2014), while needing to refrain from forgetting to take into account the growing patterns of uneven development, resource use, affluent consumption, poverty, and inequality (Bluwstein et al., 2021).

Some took note of the Limits to Growth report and have since the 1970s been advocating for a different economic system, where nature is taken account of in the economic system, instead of being externalized. Scholars have asked why this economic system that reduces persons to consumers and environment to a resources had been so widely accepted (e.g., Rozack, 1989). New economy thinkers emerged and include (but are not limited to) Gerorgescu-Roegen, Boulding, and Daly in the 70s, and also transdisciplinary thinkers such as Costanza and Spretnak in the 80s and 90s (e.g., Daly, 1973; Boulding, 1978; Costanza, 1992; Georgescu-Roegen, 1971; Spretnak, 1991). Sharlene Spretnak who co-founded the US Green Party in the 1980s is quoted in Coope (2008) to have answered a student's question in the following manner "...We are trying to reorient human society, including ourselves, to appreciate and live out basic human values-ecological wisdom, grass-roots democracy, nonviolence and so forth. To effect that kind of comprehensive transformation will surely require flexibility and creativity...".

As outlined by Boyce et al. (2002) "equity, sustainability, resilience, and the "noneconomic' dimensions of human well-being are missing in the dominant economic ideology's exclusive focus on 'efficiency'." Sustainability studies advocate how we

\footnotetext{
${ }^{2}$ https://en.wikipedia.org/wiki/Albert_Allen_Bartlett.
} 
can sustain what we have into the future, but the damages of Neoliberal Hyper Capitalism also have to be repaired to give us a chance for a future. Sustainability has worthy goals, but without economic system change, this approach has simply delivered business-as-usual with a 'green' face (less material use and more renewable energy) and/or very slow progress that could always be undone by governments (Ragnarsdottir \& Parker, 2022). For the past 15 years or so, there has been an explosion of new economy thinkers, with some of the most noted Prosperity Without Growth (Jackson, 2011), call for sustainable well-being within planetary boundaries built on ecological economics (Costanza et al., 2014, 2016, 2018, 2020a, b; Ragnarsdottir et al., 2014), Doughnut Economics (Raworth, 2017), Economy in Service of Life (Lovins et al., 2018), Economics of Arrival (Trebeck \& Williams, 2019), and Less is More (Hickel, 2020). These authors build on values and principles and goals that take us in the right direction. But I consider that only one of them, Hickel (2020), has an action plan-based on how degrowth can change the world (see Chap. 9, Sect. 9.3.4).

We were told repeatedly by government and world leaders that we could not change the economic system dramatically as it would be too big a shock-but now we already have the COVID-shock - and we need to grasp opportunities for change and find answers for building regenerative well-being economies, regenerating nature and societies for the well-being of all. Taking on the values and principles and goals and new economy thinkers is a first step, kicking in the action plan of Hicks (2020) is a good way to start build up better-as now called for by many-including the Well-being Economy Alliance. ${ }^{3}$

If healthy nature is taken as the ultimate sustainable system-when left from human intervention - of note is that nature regenerates itself through the yearly seasons (Ragnarsdottir \& Parker, 2022). Therefore, the new economy needs to be built on the principles of living systems, with equitable distribution of scarce resources to maximize well-being for people and nature within planetary limits.

\subsubsection{The Financial System}

Investment, both public and private, needs to be directed toward restorative functions (Ragnarsdottir \& Parker, 2022). Fullerton's investment model (Fullerton, 2015) mirrors his regenerative economic model (see Sect. 9.3.2) that is based on eight living system principles. His plan emphasizes that going from conventional investment we have so far embraced green investment (e.g., the Green Deal of the EU and the Green New Deal proposed in USA) and sustainable investment. But that is not enough, we need to focus on restorative investment and ultimately regenerative investment which is based on holistic thinking, patterns, and natural system design. The current conventional investment model involves neoliberal financial gymnastics

\footnotetext{
${ }^{3} \mathrm{https} / / /$ wellbeingeconomy.org/.
} 
including passive index funds and mutual funds in addition to traditional LBO (leveraged buyout, i.e., one company's acquisition of another company using a significant amount of borrowed money to meet the cost of acquisition), activist hedge funds (that have investors who purchase shares of companies and become active by shaking up management with an aim to make the voice of shareholders heard more loudly) and passive Environmental, Social, and Governance (ESG) criteria (set of standards for a company's operations that socially conscious investors use to screen potential investments; environmental criteria consider how a company performs as a steward of nature; social criteria examine how it manages relationships with employees, suppliers, customers, and the communities where it operates; and governance deals with a company's leadership, executive pay, audits, internal controls, and shareholder rights). Under green investment falls active engaged ESG. Sustainable investments involve impact investments and green bonds. Restorative investment, on the other hand, involves place-based integral capital and finally regenerative investment focuses on systemic investment with wide public-private partnerships (Fullerton, 2015).

It is important to refer to the wisdom of Satish Kumar from after the economic crash in 2008. While the financial system (banks, stock-markets, financial institutions) is in the hands of highly educated people, they have confused money with wealth; money is not wealth, money is a measure of wealth and a means to exchange wealth. "Real wealth is good land, pristine forests, clean rivers, healthy animals, vibrant communities, nourishing food, and human creativity" (Kumar, 2009). He goes on to state that we need skills not only in economy and ecology, but also in ethics - every day we hear the "...mantra of economy - while our ecology is in ruins, our ethics have been shelved, and our principles of justice and equity are put on the back burner." It is such transdisciplinary understanding of ethics, ecology, and economy that is fundamental for transformation literacy.

In this book, the not-for-profit economy presents a different pathway to a regenerative economy (Hinton; see Chap. 13 in book part 2) with social and ecological objectives that build in systemic investments, but profit goes not to the owners, but to social and ecological regeneration. The idea is that investment and profit sharing is fundamental to societal change, but can we also make our money work for our benefit? Mariana Bozesan (2020) presents her 21 principles in Integral Investing. In her book, she demonstrates how to use human-centered Artificial Intelligence (AI) to scale and digitalize the investment process. Her goal is to accelerate the use of exponential technology, capital, and consciousness leadership to transition to a sustainable global society, and this she terms the Investment Turnaround. Hence, there are many new ideas that have been represented that can aid us toward a regenerative Earth community pathway, and for that we need transformation literacy which is built on transdisciplinary and integral thinking. Finally, it is not enough to redirect our investments, the economic and finance system also needs to become just by stopping corporate tax avoidance as newly agreed by G7, ${ }^{4}$ as well as addressing the fact that democratically elected officials are unable to address challenges because elites'

\footnotetext{
${ }^{4}$ https://www.politico.eu/article/g7-seals-breakthrough-deal-to-tax-global-companies/.
} 
philanthropic engagement that appears to be fighting for equality and justice-except in ways that threaten their position at the top (Giridhardas, 2020).

\subsubsection{The Education System}

Globally and nationally the education system is still primarily along subject lines, instead of being holistic, integrative, and innovative. While environmental science and sustainable development is touched upon in schools at all levels from nurseries to universities, the holistic framework is still missing. Also the educators lack the overview to deliver holistic education. But how can we change this box-thinking trend around?

Schumacher College in Dartington, Devon, UK, is known as being one of the first educational institutions to focus on holistic education. It opened its doors in 1991. The college emerged from the Dartington Hall Trust which in the 1980s was renowned for its gardens, music, and educational experimentation (Phillips, 2008), and it was Satish Kumar who proposed the college to the Trustees. He built his vision for the college on cultural historian Tomas Berry's vision of an intimate Earth community, a community of all the geological, biological, and human components to guide us on our way to a creative future (Berry, 1988). Three decades on and thousands of people have benefitted from short courses and masters' programs at the college. As outlined by sustainability educator Stephen Sterling (a student, helper, teacher, reviewer, and University liaison of the college), many students have claimed that they felt a 'transformation' between 'before' and 'after' being at the college; environmental literacy professor David Orr states that the college has been the incubator of the most creative minds of the past decades and that the college has attracted some of the most extraordinary students that he has had the privilege to know (see Phillips, 2008). For transformation literacy to emerge globally, collages of the caliber of Schumacher College need to be established across the world.

Sterling (2004) proposed three levels of higher education response to the combined crises that we are in: (1) Accommodative response: Education about sustainability. The content/skills gained is easily accommodated into the existing system, often by adding modules about sustainability. The students learn about change. (2) Reformative response: Education for sustainability. The institution embraces additional values and embarks on greening operations, including questioning of the institutions purpose, policy, and practice. The students learn skills for change. (3) Education where students are provided with an environment where learners gain the skills they need to contribute to a more sustainable society: Education is change. The students gain sustainability literacy skills and capacity building with an emphasis on action through a 'living' inquiry-based curriculum. The focus is on becoming permeable, experiential communities and organizations. The students learn to become change makers. It is the third level of response that is needed for transformation literacy to emerge. As suggested by Phillips (2009), curricula of institutions will have to be 
revisited time and again, and be re-examined to see whether and how they contribute to the critically important agenda of re-orientating education toward sustainability.

Epistemic transformation involves a distinctive kind of change in the way we understand the world, one that comes from having a new kind of experience (Paul \& Quiggin, 2021). A successful university education can transform through creating a distinctive, mentally significant kind of epistemic transformation that, in turn, creates personal transformation. Such personal transformation stems from a radical epistemic transformation that scales up into a change in "who we are" (Paul \& Quiggin, 2021), and has been described being constituted by a change in one or more core personal preferences (Paul, 2014) that iterate out into a substantive shift in one's desires, self-awareness, belief structure, and lived experience. While these studies are for university education in general, it can be applied to what kind of mentally significant epistemic transformations create personal transformation that leads to the students wanting to become change makers for sustainability. I thus view such epistemic and personal transformations as being an important part of underpinning transformation literacy.

Some of the new economic thinking that has emerged is that of the Circular Economy promoted by the Ellen MacArthur Foundation (EMF, 2013) and adapted into policy by the EU with strategy in 2015 and updated action plan $2020^{5}$ and is further supported by the Global Alliance of Circular Economy and Resource Efficiency (GACERE) of 2021. ${ }^{6}$ The skills that are needed for the circular economy call for a shift in education at all levels with particular emphasis on: product design and production, new business models, building cascades/reverse cycle, and as well as enablers to improve cross-cycle and cross-sector performance. These include crosscycle and cross-sector collaboration facilitating factors, favorable investment climate, rules of the game to quickly reach scale and education to raise awareness in general public and business committee as well as integration of circular concepts in university curricula (EMF, 2013).

The decade of Education for Sustainable Development (ESD) ${ }^{7}$ set forth by UNESCO 2005-2014 has impacted school curricula around the world, but the conservative university establishments have paid less attention. While many higher education institutions around the world have created courses that provide transdisciplinary inquiry that leads to the students being able to become change makers upon graduation, to my knowledge, no university has had the level of transformation needed as outlined in Sterling (2004). Educational institutions are conservative and hold on to the subject specialties, because promotions require publication of research in certain "prestigious" journals, and newer inter- and trans-disciplinary journals do not carry the same prestige. In my own experience, I did not start to work on interdisciplinary research pertaining to sustainability until I had been promoted to full professor. Many young academics are frustrated at the lack of flexibility in the higher education "system" and university boards need to have a re-think about what sort

\footnotetext{
${ }^{5}$ https://ec.europa.eu/environment/strategy/circular-economy-action-plan_de.

${ }^{6}$ https://ec.europa.eu/environment/international_issues/gacere.html.

${ }^{7}$ https://en.unesco.org/themes/education-sustainable-development/what-is-esd/un-decade-of-esd.
} 
of research is important for society in order to support education for sustainability, let alone transformation skills.

Parallel to the development of Schumacher College was the discussion about first environmental literacy in the 1980s and 1990s (Mosley, 2000) and later sustainability literacy (Stibbe, 2009). Futures literacy is an important new concept for training members of society and policy makers to understand our responsibility for future generations and the future of the planet. Futures studies is a relatively new discipline at higher education level, providing comprehensive, multidisciplinary, and practical education for futures thinking (Wilenius \& Haonen, 2017). Our education is based on history that takes us back to the beginning of agriculture (7000 years), but thinking into the future is mostly left out of education. One futures program that provides futures literacy in educating futurists is worth mentioning at the University of Turku in Finland, ${ }^{8}$ and more programs are starting around the world. The fact is that people's behavior has not changed adequately and the future of our society and our Earth is in peril. I conclude that it is necessary for schools and universities to reform curricula in order to allow progress toward transformation literacy and futures thinking - as presented in this book.

\subsubsection{The Innovation System}

When referring to the innovation system, people are usually referring to innovation that leads to entrepreneurial activities and the establishment of new enterprises. Small- and medium-size enterprises are the foundation for the economies of many of the most successful countries in Europe, including Germany and Sweden. Many countries now have innovation ministries. Universities and related institutions are more and more supporting the incubation of entrepreneurial activities by setting up science parks, as well as competitions for innovators to take part in mentoring events, but the stumbling block often is that the person with the "new idea"-or innovator, often is not a clever business wo/man and suffers from not having the skills to set forth a successful business plan. As I have learned from developing and leading research projects, innovators need to learn to work with people that complement their own skills.

There is a need to understand the match between types of innovation and incubator archetypes (Barbero et al., 2014). The archetypes of incubator include basic research, university-, economic development-, and private incubators, and analysis has shown that they generate different types of innovation (i.e., product, technological process, and organizational innovation). But innovation is generally aimed at building new companies that generate jobs and fuel economic growth. Can innovation be used to help nations adapt to a new economy that supports the transition needed that we are promoting in this book? Goal 9 of the United Nations Sustainable Development Goals is to build resilient infrastructure, promote inclusive and sustainable industrialization,

${ }^{8}$ https://www.utu.fi/en/study-at-utu/masters-degree-programme-in-futures-studies. 
and foster innovation. The Innovation Union ${ }^{9}$ of the European Union is one of the seven flagship initiatives of the Europe 2020 strategy for a smart, sustainable, and inclusive economy. The European Institute of Innovation Technology (EIT) has the overall mission to stimulate sustainable EU economic growth and competitiveness by strengthening the innovative capacity of Member States and the Union. Therefore, there is a gap between the EU policy of growth and the European Green Deal ${ }^{10}$ which aims to transform the EU into a modern, resource-efficient, and competitive economy ensuring no net emissions of greenhouse gases by 2050, economic growth decoupled from resource use, and no person and no place left behind. The focus is on economic growth which we have demonstrated in this book to be incompatible with living within the planetary boundaries.

In her book, The Entrepreneurial State, the economist Mariana Mazzucato (2018), gives evidence to the fact that behind the large majority of innovations lies state funding. This revelation holds from new drugs to smartphones. The logical derivation is that for a nation to build up their small- and medium-size enterprises, create jobs, and stay ahead of the curve, transdisciplinary education with emphasis on natural sciences and systems thinking is key. It follows that universities and the state alike need to provide incubator spaces for technology and business development that are compatible with a healthy planet. As emphasized by Rutger Bregman in Utopia for Realists (2017), the reason why the large majority of innovation companies are in the US is because that is where the Venture Capitalists jump on board, once the government funding has provided the funding for proof of concept if not more. There is thus a need for national policies to be set in the USA, EU, and elsewhere for supporting the need for sustainable development and transitioning to a world within planetary boundaries with the well-being of all at heart. The innovation system needs transition literacy just like the other systems addressed here.

\subsubsection{Other Systems}

In our complex world, there are other systems that are very important and have a huge impact on the Earth system, but this introduction cannot go into them all in detail. Worthy of mentioning is the Food System that feeds 7.9 billion people around the world and has a huge impact on the degradation of soils, biodiversity loss, water use, and greenhouse gas emissions, affecting the Biological Systems and the Climate System. These systems were scrutinized in 2021 in the UN Food System Summit, ${ }^{11}$ the UNEP Biodiversity Conference, ${ }^{12}$ and the UN Climate Conference. ${ }^{13}$

\footnotetext{
${ }^{9}$ https://www.europarl.europa.eu/ftu/pdf/en/FTU_2.4.6.pdf.

${ }^{10} \mathrm{https}$ //ec.europa.eu/info/strategy/priorities-2019-2024/european-green-deal_en.

11 https://www.un.org/en/food-systems-summit.

12 https://www.unep.org/events/conference/un-biodiversity-conference-cop-15.

13 https://ukcop26.org/.
} 
Also worthy mentioning are Urban Systems - with over 50\% of the world's population now residing in urban areas as well as alternative Community Systems that focus on cooperation and sustainability-including Ecovillages, ${ }^{14}$ Transition Towns ${ }^{15}$ and Co-housing ${ }^{16}$ projects. I should not forget to mention Energy Systems, where the transition to renewables is paramount.

Last but not least, I here outline how the international Criminal Law System could be the biggest one step that humanity can take in getting us on the right path by making "ecocide" the fifth crime against humanity through inclusion in the Rome Statute $^{17}$ of the International Criminal Court. Ecocide law was first outlined by the late Polly Higgins in her book Eradicating Ecocide (2010). New definition of "ecocide" by twelve international and environmental lawyers ${ }^{18}$ is gaining interests by political leaders, including in France and Pacific Islands.

All of these systems (and more) have an effect on systems outlined above: the Earth system, the Economic System, the Financial System, the Education System, and the Innovation System. And the complexity is ever increasing.

In the following contributions of this book, emerging bottom-up systems are highlighted that allow communities for change to take charge of their future, and connect local to global system designs that are likely to support pathways toward a regenerative world. The contributions show concepts and implementation attempts of regenerative approaches to human-to-human and human-to-nature interactions that showcase a new operating model for humankind. They come from a wideranging spectrum and illustrate that the entry points for transformative change toward regenerative civilizations may come from very different angles. The contributors showcase exemplary systems that model collective stewardship of planetary wellbeing.

Chapter 9 by Kristin Vala Ragnarsdottir presents the rationale for why visioning a regenerative world in the future is important. Based on the visioning strategy of Donella Meadows, the future is envisioned from 2021 onward. In addition to answering the questions of Meadows of how a regenerative world would look like, the importance of building a sustainable economy is outlined, an economy that regenerates the natural world and communities. Several models have been outlined, and in this chapter, the focus is on the well-being economy, the regenerative economy in service of life, and the doughnut economy. An action plan is presented of how to direct the economy to operate within planetary boundaries based on degrowth for the global North. Other systems that are briefly outlined as being important include sustainable natural and food systems. All of these systems are interconnected in a complex manner and therefore need to be studied together.

\footnotetext{
14 https://ecovillage.org/.

$15 \mathrm{https}: / /$ transitionnetwork.org/.

16 https://www.cohousing.org/; https://cohabitas.com/a-visit-to-saettedammen-co-housing/.

${ }^{17} \mathrm{https} / / / \mathrm{www} . \mathrm{icc}-\mathrm{cpi}$.int/resource-library/documents/rs-eng.pdf.

18 https://www.stopecocide.earth/press-releases-summary/top-international-lawyers-unveil-defini tion-of-ecocide.
} 
Chapter 10 by Ingrid Stjernquist and Peter Schlüter examines from a systems and livelihood perspective, using the Nemoral and Boral forest zones of the Global North and Sweden as an example, how forestry can meet current and future sustainability challenges, in particular with regard to climate change, both as a traditional resource base and with respect to other ecosystem services. Previous and current forest policy and governance is briefly described against the background that Swedish forestry is based both on a small number of very large industrial forest owners and a multitude of small individual, family, owned forest estates. Environmental issues have over time increased in weight as have the forest owners' degrees of freedom to manage their forests. However, increasing conflicts between different policy objectives are likely in the future. Multiple demands on the forest are poorly prioritized and analyzed. Successful delivery against objectives like biomass resource extraction, biodiversity preservation, increased carbon storage, etc., will require careful balancing and the active participation of local forest owners. The cumulative effects of old and new societal demands on forestry and their impact on local livelihoods pose in this respect a systemic risk as little consideration has been given to economic and social sustainability. There is a need for a more synoptic and systemic analysis of how, not only traditional, forestry is affected by multiple and partly contradictory demands and expectations from an increasing array of stakeholders, but also in order to enable a move toward a bio-based economy and a renewable and sustainable energy system. The authors suggest stakeholder-based group modeling as powerful analytic and conflict reducing approach in order to improve forestry contribution to the acute need to handle the climate change and sustainability challenges.

Chapter 11 by Catharina Any Sulistyowati and Renny Nurhasana outlines the role of capacity building of local NGOs in Sumba, a poor island in the Eastern part of Indonesia. It is part of a larger initiative referred to as Sumba Iconic Island (SII), which aimed to solve poverty problems, transforming unequal gender relations while at the same time mitigating climate change. This study traced what happened in the six years after the project ended. It was done by exploring the project documentation and conducting interviews with the development agency's staff and program alumni representatives. Findings are that the capacity building has improved nature, community well-being, women leadership, and more equal gender relations. The chapter concludes that: (1) transformation is not a linear process, (2) the changes toward the vision are not direct but tortuous; (3) there are unintended consequences, which can be positively or negatively influence the initial goal; and (4) the capacity to analyze the situation, reflect, and create action is crucial in the transformation process.

Chapter 12 by Justine Braby and Reinhold Mangundu presents the results of various approaches used by a group of young Namibians to shift the society toward a well-being economy. They sought to find more appropriate measurements of success and did this by conducting (a) a survey to measure progress, (b) different dialog processes to understand what a good quality of life actually means to citizens, 
(c) co-constructing community well-being from the bottom-up, (d) communication, networking, and awareness to garner public support, and finally (e) attempting to influence high-level decision making in government. The authors measured nine domains, of which state of mind and perceived health were the only domains found to be sufficient. The domains community strength and sense of belonging were the lowest in the high-income area. The domains with the highest levels of dissatisfaction were good governance and political freedom. The process of co-constructing community well-being through a bottom-up approach had varying levels of success and was highly adaptive and flexible. The key findings were that the underlying components of well-being was trust (at all levels), a sense of belonging and healthy relationships, basic needs (home, food, water, sanitation, electricity), quality education (the kind that causes critical and systems thinking and develops creative potential), quality work (that is demanding and rewarding), and good health.

Chapter 13 by Jennifer Hinton offers an overview and explanation of how society's relationship to profit plays a significant role in determining social and ecological outcomes. The way in which societies relate to profit plays out in terms of both formal and informal institutions. One formal institution that is key for sustainability is relationship-to-profit; the legal difference between for-profit and notfor-profit forms of business. Hinton explains how relationship-to-profit, as a basic building block of the entire economy, plays a critical role in determining whether the economy drives sustainability crises or allows for meeting everyone's needs within the ecological limits of the planet. Her analysis reveals that the social and ecological crises of the twenty-first century have the same driver: the pursuit and accumulation of private wealth inherent in the for-profit economy. Yet, existent not-for-profit types of business offer a viable way out of this conundrum. As a non-capitalist market economy, this model paves a way beyond the traditional market-state dichotomy and the stagnant discourse over whether sustainability requires more state or more market interventions, allowing for more fruitful discussions and more systemic interventions.

Chapter 14 by Jenneth Parker discusses the example of Wales in some depth in order to give insights to how and why a well-being economy approach has been successfully initiated there, and some idea of its future prospects. The systems aspects of well-being economy are identified as being inherent in ambitions to develop transitional strategies that can achieve system change through combinations of measures across different aspects of economy, society, and ecology. Parker's analysis points to some of the ways that well-being economy can provide opportunities for progressive political actors, and vice versa. She concludes with some general points about the value of systems tools and approaches in helping to really bring well-being economy topics off the page and into reality. In particular, the complexity of the task of well-being economy is suited to systems approaches that can help to map coherent relationships between different areas and also aid in moving from loose alliances to more synergies. These tools and approaches can be powerful when combined with the extensive local knowledge and motivation that exists wherever we find communities and individuals working for a better future. Questions are also raised about the need for Well-being Economy Alliances to work together with other international actors in reforming the structures of the international economy at global scale. 


\section{References}

AtKisson, A. (2008). The ISIS agreement. How sustainability can improve organizational performance and transform the world. Routledge.

AtKisson, A. (2010). The sustainability transformation: How to accelerate positive change. Routledge.

Barbero, J. L., Casillas, J. C., Wright, M., \& Ramos Garcia, A. (2014). Do different types of incubators produce different types of innovations? Journal of Technology Transfer, 39, 151-168.

Bardi, U. (2011). The limits to growth revisited. Springer Briefs in Energy. Springer.

Berry, T. (1988). The dream of the earth. Sierra Books.

Bluwstein, J., Asiyanbi, A. P., Dutta, A., Huff, A., Friis Lund, J., De Rosa, S. P., \& Steinberger, J. (2021). Commentary: Underestimating the challenges of avoiding a ghastly future. Frontiers in Conservation Science. https://doi.org/10.3389/fcosc.2021.666910

Boulding, K. E. (1978). Ecodynamics: A new theory of societal evolution. Sage Publications.

Boyce, J. K., Narain, S., \& Stanton, E. A. (2002). Introduction. In: J. K. Boyce, S. Narain, \& E. A. Stanton (Eds.), Reclaiming nature. Environmental justice and ecological restoration. Anthem Studies in Development and Globalisation. Anthem Press.

Bozesan, M. (2000). Integral investment. From profit to prosperity. Springer.

Bradshaw, C. A., Ehrlich, P. R., Beattie, A., Ceballos, G., Crist, E., Diamond, J., Dirzo, R., Ehrlich, A. H., Harte, J., Harte, M. E., Pyke, P., Raven, P. H., Ripple, W. J., Saltre, F., Turnbull, C., Wackernagel, M., \& Blumstein, D. T. (2021). Underestimating the challenges of avoiding a ghastly future. Frontiers in Conservation Science. https://doi.org/10.3389/fcosc.2020.615419

Bregman, R. (2017). Utopia for realists, and how we can get there. Bloomsbury Publishing.

Coope, J. (2008). The ecological blind spot in postmodernism. In: W. Wheeler \& H. Dunkerley (Eds.), Earthographies: Ecocriticism and culture. New formations (vol. 64, pp. 78-89).

Costanza, R. (1992). Ecological economics: The science and management of sustainability. Complexity in Ecological Systems series. Columbia University Press.

Costanza, R., Kubiszewski, I., Giovannini, E., Lovins, H., McGlade, J., Pickett, K. W., Ragnarsdottir, K. V., Roberts, D., de Vogli, R., \& Wilkinson, R. (2014). Development: Time to leave GPD behind. Nature, 505, 282-285.

Costanza, R., Daly, L., Fioramonti, L., Giovannini, E., Kubiszewski, I., Mortensen, L. F., Picett, K., Ragnarsdottir, K. V., de Vogli, R., \& Wilkinson, R. (2016). The UN sustainable development goals and dynamics of well-being. Solutions, 7(1), 20-22.

Costanza, R., Daly, L., Fioramonti, L., Giovannini, E., Kubiszewski, I., Mortensen, R. F., Pickett, K. E., Ragnarsdottir, K. V., de Vogli, R., \& Wilkinson, R. (2020a). Measuring sustainable wellbeing in connection with the UN sustainable development goals. Ecological Economics, 130, 350-555.

Costanza, R., Fioramonti, L., Giovannini, E., Kubiszewski, I., Lovins, H., McGlade, J., Mortensen, L. F., Pickett, K., Ragnarsdottir, K. V., Roberts, D., Trebeck, K., de Vogli R., Wallis, S., \& Wilkinson, R. (2020b). After the crisis: Two possible futures. Solutions, September issue. https:// thesolutionsjournal.com/article/crisis-two-possible-futures/.

Costanza, R., Caniglia, B., Fioramonti, L., Kubiszewski, I., Lewis, H., Lovins, L. H., McGlade, J., Fogh Mortensen, L., Pilipsen, D., Pickett, K. E., Ragnarsdottir, K. V., Roberts, D., Sutton, P., Trebeck, K., Wallis, S., Ward, J., Weatherhead, M., \& Wilkinson, R. (2018). Toward a sustainable wellbeing economy. Solutions, 9(2), April issue. https://www.thesolutionsjournal.com/article/tow ard-sustainable-wellbeing-economy/.

Daly, H. (1973). Toward a steady-state economy. W.H. Freeman \& Co.

EMF. (2013). Towards The Circular Economy, economic and business rationale for an accelerated transition. Ellen MacArthur Foundation, Isle of White, UK.

FAO (2015). Status of the World Soil Resources (SWSR)—Main report, $650 \mathrm{pp}$. Food and Agriculture Organisation of the United Nations and Intergovernmental Technical Panel on Soils, Rome, Italy. http://www.fao.org/3/i5199e/i5199e.pdf.

Fullerton, J. (2015). Regenerative capitalism. How universal principles and patterns will shape our new economy. Capital Institute. 
Georgescu-Roegen, N. (1971). The entropy law and the economic process. Harvard University Press.

Giridharadas, A. (2020) Winners take all: The elite charade of changing the world. Penguin.

Hartwell, R. M. (1995). A history of the Mont Pelerin society. Liberty Fund Inc.

Heinberg, R. (2001). Peak everything. Waking up to the century of decline in earth's resources. Clairview Book.

Heinberg, R. (2005). The party's over. New Society Publishers.

Heinberg, R. (2011). The end of growth. New Society Publishers.

Hickel, J. (2020). Less is more. How degrowth will save the world. William Heinemann.

Higgins, P. (2010) Eradicating ecocide. Laws and governance to stop the destruction of the planet. Shepheard-Walwyn.

IBPES. (2019). Global assessment report on biodiversity and ecosystem services of the intergovernmental science-policy platform on biodiversity and ecosystem services (E.S. Brodizio, J. Settele, S. Diaz, \& H. T. Ngo (eds.)), 63 pp. IPBES secretariat.

Jackson, T. (2011). Prosperity without growth. Economics for a finite planet. Routledge.

Kanninen, T. (2013). Crisis of global sustainability. Routledge Global Institutions Series 74, New York.

Kenton, W., \& Kelly, R. C. (2021). Neoclassical economy. Investopedia. https://www.investopedia. com/terms/n/neoclassical.asp.

Kenton, W., \& Westfall, P. (2020). Neoliberalism. Investopedia. https://www.investopedia.com/ terms/n/neoliberalism.asp.

Kumar, S. (2009). Grounded economic awareness. In A. Stibbe (Ed.), The handbook of sustainability literacy. Skills for a changing world. Green Books.

Kuenkel, P. (2019). Stewarding sustainability transformations. An emerging theory and practice of SDG implementation. Springer International Publishing.

Lovins, L., Wallis, S., Wijkman, A., \& Fullerton, J. (2018). A finer future. Creating and economy in service of life. New Society Publishers.

Mazzucato, M. (2018). The entrepreneurial state: Debunking public vs. private sector myths. Penguin.

Meadows, D. H., Meadows, D. L., Randers, J., \& Behrens, W. (1972). Limits to growth. Universe Books.

Meadows, D. H., Meadows, D. L., \& Randers, J. (1992). Beyond the limits. Confronting global collapse, envisioning a sustainable future. Chelsea Green Publishing Company.

Meadows, D. H., Randers, J., \& Meadows, D. L. (2004). Limits to growth. The 30 year update. Universe Press.

Mosley, C. (2000). Teaching for environmental literacy (vol. 74, issue 19, pp. 23-24). The Clearing House.

Nörgård, J. S., Peet, J., \& Ragnarsdottir, K. V. (2010). The history of limits to growth. Solutions, 1(2), 59-63.

Paul, L. A. (2014). Transformative experience. Oxford University Press.

Paul, L. A., \& Quiggin, J. (2021). Transformative Education. Educational Theory, 70(5), 561-579.

Phillips, A. (2008). Holistic education. Green Books.

Phillips, A. (2009). Institutional transformation. In A. Stibbe (Ed.), The handbook of sustainability literacy. Skills for a changing world. Green Books.

Powell, J. F. (1971). Attack on American free enterprise system. Written for the U.S. Chamber of Commerce. https://www.greenpeace.org/usa/democracy/the-lewis-powell-memo-a-corporateblueprint-to-dominate-democracy/.

Ragnarsdottir, K. V., \& Parker, J. (2022) Regenerative welbeing economy. In J. Blewitt (Ed.), New economy, new systems, forthcoming.

Ragnarsdottir, K. V., \& Sverdrup, H. (2015). Limits to growth revisited. Geoscientist, 25(9), 10-15.

Ragnarsdottir, K. V., Costanza, R., Giovannini, E., Kubiszewski, I., Lovins, H., McGlade, J., Pickett, K. E., Roberts, D., de Vogli, R., \& Wilkinson, R. (2014). Beyond GDP. Exploring the hidden links between geology, economics and well-being. Geoscientist, 24(9), 12-17. 
Raworth, K. (2017). Doughnut economics. Seven ways to think like a 21st-century economist. Random House.

Rozack, T. (1989). Where the wasteland ends: Politics and transcendence in postindustrial society. Celestial Arts.

Spretnak, C. (1991). States of grace: The recovery of meaning in the postmodern age. Harper.

Steffen, W., Broadgate, W., Deutsch, L., Gaffney, O., \& Ludviw, C. (2015). The trajectory of the Anthropocene: The great acceleration. The Anthropocene Review, 2(1), 81-89. https://doi.org/10. $1177 / 2053019614564785$

Sterling, S. (2004) Higher education, sustainability, and the role of systemic learning. In P. B. Corcoran, \& A. E. J. Wals (Eds.), Higher education and the challenge of sustainability, 49-70. Springer.

Stibbe, A. (Ed.). (2009). The handbook of sustainability literacy. Green Books, Totnes.

Sverdrup, H. U., \& Ragnarsdottir, K. V. (2014). Natural resources in a planetary perspective. Geochemical Perspectives, 3(2), 129-341.

Trebeck, K., \& Williams, J. (2019). The Economic of Arrival. Policy Press, University of Bristol, Bristol.

Turner, G. (2012). On the cusp of global collapse? Updated comparison of the limits to growth with historical data. GAIA Ecological Perspectives for Science and Society, 21(2), 116-124.

Turner, G. (2014). Is global collapse imminent? An updated comparison of the limits to growth with historical data. MSSI Research paper 4, $21 \mathrm{pp}$.

Wilenius, M., \& Halonen, T. (2017). Patterns of the future: Understanding the next wave of global change. World Scientific Publishing Europe Ltd.

Zalasiewicz, J., Waters, C. N., Ellis, E. C., Head, M. J., Vidas, D., Steffen, W., Adeney Thomas, J., Horn, E., Summerhayes, C. P., Leinfelder, R., McNeill, J. R., Galuszka A., Williams, M., Baronsky, A. D., de Richter, D. B., Gibbard, P. L., Syvitski, J., Jeandel, C., Cearreta, A., Cundy, A. B., Fairchild, I. J., Rose, N. L., Ivar do Sul, J. A., Shotyk, W., Turner, T., Wagreich, M., \& Zinke, J. (2021). The anthropocene: Comparing its meaning in geology (chronostratigraphic) with conceptual approaches arising in other disciplines. Earth's Future, 9(3). https://doi.org/10. 1029/2020EF001896.

Open Access This chapter is licensed under the terms of the Creative Commons Attribution 4.0 International License (http://creativecommons.org/licenses/by/4.0/), which permits use, sharing, adaptation, distribution and reproduction in any medium or format, as long as you give appropriate credit to the original author(s) and the source, provide a link to the Creative Commons license and indicate if changes were made.

The images or other third party material in this chapter are included in the chapter's Creative Commons license, unless indicated otherwise in a credit line to the material. If material is not included in the chapter's Creative Commons license and your intended use is not permitted by statutory regulation or exceeds the permitted use, you will need to obtain permission directly from the copyright holder. 